\title{
Understanding Students' Psychological Distress Complaints through Online Academic Advising Support
}

\author{
Askar Askar', Adawiyah Adawiyah' ${ }^{2}$, Nurdin Nurdin ${ }^{3}$ \\ ${ }^{1}$ Associate Professor Department of Islamic Education and Training, ${ }^{2}$ Senior Lecturer Department of Education \\ Management, ${ }^{3}$ Professor Department of Islamic Economic and Business, Institut Agama Islam Negeri (IAIN) Palu, \\ Indonesia
}

\begin{abstract}
The purpose of the study is to investigate students' psychological distress complaints through an online webbased academic advisor support. This study employed a qualitative method. Data were gathered through indepth anonymous consultation and interview which were conducted through online facilities, such as email, WhatsApp, and telephone, to understand the students' psychological distress complaints. The data, then, were analyzed using the grounded theory approach through open, axial, and theoretical coding. The results of this study showed that five main issues that caused psychological distress have been complained by students through the online advising service centre. Those issues included feeling distress towards campus unfair treatment, bureaucracy complexities, lack channel to express complaints, unfriendly academic advisors, and opposite-sex advisors issue. This study concludes that the online advising support center can be used to support students' psychological relief because the system increases anonymity, reduce physical contact, and avoid opposite sex barriers during psychological consultation. This study promotes the use of online academic advising support to increase students' intention to use an academic advising support in order to reduce stress and promote students' mental health.
\end{abstract}

Keywords: psychological distress, online advising, academic advising, university students

\section{Introduction}

Recent interest in students' psychological distress complaints and grievances related to campuses environments have caused more researchers to study academic advising roles in solving the issues. Prior studies highlight that the increase in the number of psychological distress complaints in higher education institutions mostly relates both to quality and standards in campus services and lack response to student demands as a 'consumer'.

University students experience psychological distress at an early stage of study or during the whole process of the study. Unresolved psychological distress have resulted in increasing number of students to take study leave for a certain period ${ }^{2}$. This phenomenon is worse when a campus does not have academic advising and help support center. Students might keep the stressful situation without a solution which may cause their education failure ${ }^{3}$.
Prior studies point out that higher education students who experience a high prevalence of complaints and grievances may result in higher levels of psychological distress $^{4,5}$. Relationship between students mental health with academic success have been found in previous studies $^{6,7}$.

In some cases, students' psychological support merely rely on an academic advisor who takes care for specified number of students according a campus regulator appointment through a face to face academic advising service center ${ }^{3}$. However, prior studies ${ }^{8,9}$ found that very limited students use face to face academic advising support center. Even though some students may use the services, but most of them are not satisfied ${ }^{9,10}$. The reasons behind low usage of conventional face to face academic advising services include cultural issues, reluctant toward physical contact, and lack of anonymity ${ }^{11}$. 
Academic advising may become an essential element for learning success in Islamic universities environments, but it has received little attention from researchers. Since academic advising can contribute to improving the satisfaction and retention of students, research on this activity is especially needed in the current situation of the competition among Islamic universities in Indonesia and across the globe. Lack of studies of academic advising within Islamic education institutions may cause lack of academic literature and hinder the development of the institutions.

This study, therefore, explores a university students use of online academic advising services to express psychological distress related to campus life. It is expected to shed light on how a university students use online academic advising services to relief their psychological distress. Understanding the phenomenon through online advising service not only help the students solve their psychological problem, but also help universities to improve services. The result could also be used to assist universities in providing quality, accurate and consistent advising services to their students

\section{Methodology}

This study used qualitative approach. Data were gathered from in-depth interview with 28 Muslim university students who used an online academic advising service. The online academic advising services were provided by three professional advisors who responded to students consultations through various online instruments such as online chat, e-mail, and telephone call.

In-depth semi-structured interviews were implemented with each of the students through online chat, email, and telephone. These interviews took approximately 30 minutes to 45 minutes. Students were free to choose the communication facilities provided on the website.

The interviews were analyzed using grounded theory approach as outlined by Strauss and Corbin ${ }^{12}$. A list of descriptive codes was created based on the general themes and topics identified by the researchers during the interviews and transcription. Memoing, which involves creating short descriptive headings based on the patterns and quotations identified, was used to describe and analyze the patterns that were found. The organized descriptive statements were then interpreted by the researchers ${ }^{13}$. From the interpretation, five main themes were emerged to explain the phenomena of this study.

\section{Results}

Since this study was conducted in an Islamic university context, advisors also asses the role of religion and level of religiosity among the student, they should seek to identify and integrate positive academic and campus environment problems coping strategies from Islam perspectives ${ }^{14,15}$. Base on the analysis of the data, we found five main themes emerged from all online academic consultation sessions. Each theme is presented in the table 1 below:

Table 1. Themes emerged from online consultation

\begin{tabular}{|c|c|c|}
\hline Themes & Quotes & $\begin{array}{c}\text { Participant' } \\
\text { codes }\end{array}$ \\
\hline Unfair Feeling & $\begin{array}{r}\text { My house shows distantness that is far from the economic perspective. My house is } \\
\text { made of simple planks, while the house of my friend who gets the scholarship is made of } \\
\text { permanent concrete that looks luxurious. I showed the picture of my friend's house to the } \\
\text { scholarship selection committee but they just ignore it. I was really upset with the process } \\
\text { of scholarships awardees determination for poor students at the university. }\end{array}$ \\
\cline { 2 - 4 } & $\begin{array}{l}\text { I tried to talk to the vice dean of students affairs, and he said to me that the scholarship } \\
\text { had been distributed fairly and the awarded students are based on government regulation } \\
\text { in which students have good academic records and from low-income families. Impossible } \\
\text { a student gets the scholarship without those requirements even though he/she has a family } \\
\text { member within this faculty. However, when I gave him the name of a student from a } \\
\text { wealthy family got the scholarship, he keeps quiet and walk away }\end{array}$ & ANW \\
\hline
\end{tabular}




\section{Cont... Table 1. Themes emerged from online consultation}

\begin{tabular}{|c|c|c|}
\hline \multirow{2}{*}{$\begin{array}{l}\text { Bureaucracy } \\
\text { Inertia }\end{array}$} & $\begin{array}{l}\text { I have applied for the award twice and I have completed all the requirements, but when I } \\
\text { put in the file to the office, they said bring it to another room. When I went to the room, the } \\
\text { staff said the place you visited before was right, and I went back to the first room I visited. } \\
\text { The staff, then, checked my files and he said my document is not completed. The next day } \\
\text { when I completed the file, they said again that he forgot to let me know another document } \\
\text { to be completed. Why didn't they said from the beginning that the file is still lacking? }\end{array}$ & BDI \\
\hline & $\begin{array}{l}\text { I had been on leave for one semester due to financial problem. When I came back to } \\
\text { campus, I was ordered to show my last study result record. However, instead of telling me } \\
\text { how to obtain the record, the staff asked me to meet my academic advisor first. After a few } \\
\text { days in difficulties to meet my supervisor, my problem was still not resolved. I was told to } \\
\text { go back to the academic office center and asked for an academic record }\end{array}$ & ZNA \\
\hline \multirow{2}{*}{$\begin{array}{l}\text { A Feeling of } \\
\text { not welcome }\end{array}$} & $\begin{array}{l}\text { I once met my academic advisor. When I met him like being angry, he was busy calling and } \\
\text { then walking crisscross in the room without looking at me. I waited a long time, and then } \\
\text { he said you could come tomorrow? He wanted to meet someone, it was very important, } \\
\text { he said. In fact, I just want him to sign my document. He culd immediately sign it, but he } \\
\text { rejected it. I felt like I was not appreciated. Now I am not interested to meet my academic } \\
\text { advisor unless it is really very urgent. }\end{array}$ & ARM \\
\hline & $\begin{array}{c}\text { I came to the office to obtain a recommendation letter to join a sports competition. A staff } \\
\text { said" why you are going to go to a taekwondo competition? You do not look like a fit man". } \\
\text { Instead of motivating me, she made me down. I expected she just gave the letter and I will } \\
\text { go away". }\end{array}$ & MHD \\
\hline \multirow{2}{*}{$\begin{array}{l}\text { Opposite } \\
\text { Sex Advisors } \\
\text { Resistant }\end{array}$} & $\begin{array}{l}\text { I met my advisor during lunch time because he said he has time during break time from } 12 \\
\text { to } 1 \text { o'clock midday. I came to his room and situation was very quiet because other lectures } \\
\text { were not there. I discussed my matter with him. I feel not comfortable because it was only } \\
\text { him and me in the room. I think it was a sin being in a room with a man. He also looked at } \\
\text { me differently. }\end{array}$ & LNY \\
\hline & $\begin{array}{l}\text { I am not really worried about sin when I meet with my supervisor. I only feel embracing to } \\
\text { discuss a personal problem with her. If the problem is about academic, I will discuss with } \\
\text { her, but when a problem is a bit personal, I don't dare to talk to her. }\end{array}$ & RHM \\
\hline $\begin{array}{l}\text { Overload } \\
\text { Problem }\end{array}$ & $\begin{array}{l}\text { Sir, I am stress out every day because there are so many problems that I face. I don't know } \\
\text { where to go. I want to talk to my parents, but they live far away in the village, I want to } \\
\text { talk to my friends, but I feel ashamed, and I think they cannot solve my problem. I want to } \\
\text { speak with academic advisors, but I never meet him. Luckily there is this online counseling, } \\
\text { and I can release my thoughts a little. }\end{array}$ & AGS \\
\hline
\end{tabular}




\section{Discussion}

The findings show that four themes have emerged from the data. The themes reflect the students' psychological distress complaints relating to fairness in accessing campus services, rigid bureaucracy, unavailability of a channel to put complaints, and moral issue regarding sex opposite advisor.

The university treatment in providing services has become a major concern of students within the university. The services provision is considered as unfair in which particular students did not have a similar chance in accessing a service. Feelings of fairness or unjust experienced by students in the university have also been found in another university context ${ }^{16}$. The cause of unfairness feeling is negative treatments from an organization ${ }^{17}$, unfair offers ${ }^{18}$, and sadness ${ }^{19}$.

The impact of unfairness feeling is that the emergence of emotional attributes such as anger and frustration. Such feelings may affect the students' relationship with friends, teaching staff, and campus bureaucracy. In a particular situation, a sense of being unfairly treated or experience discrimination may also cause withdrawal from the situation. In this study, the students may discontinue study or take study break as found by Lee \& Rice $^{20}$ and Brown ${ }^{21}$.

The university bureaucracy in service provision exacerbated Students' dissatisfaction towards unfair treatment. A university service quality has been found related to its functional service quality which includes service process and interpersonal interaction within the campus bureaucracy ${ }^{22}$. In this study, rigid and unclear bureaucracy related to the university services process and difficulties in interacting with teaching and administrative staff resulted in high psychological stress among students as revealed during online academic advising sessions.

Meanwhile, a feeling of not being accepted (not welcome) is often associated with rejection by the approached party ${ }^{23}$. This kind of feeling causes someone to feel lonely. Even if an academic advisor cannot serve a student at the requested time, the student may understand if the advisor respects the student and gives good reasons.
In this study context, the problem is not whether or not the service can be provided at the time required, but creating acceptance attitude by an academic advisor is essential. The attitude of accepting well by the academic advisor will increase bonds between students and their academic advisor ${ }^{24}$ more open in conveying their problems and also in conducting consultations that are more equitable. As a result, the students' openness and better support from an academic advisor can boost their success $^{25,26}$.

The students, frustrations are also reflected in their recognition that they have been reluctant to see their appointed supervisor again. The feeling also causes them to consider their future studies. For example, some students say that various kinds of problems they face and do not know where to complain, causing them to be lazy to go to college. The finding consistent with previous studies which found that the number of personal problems faced by students can result in dropping out of college students ${ }^{27}$.

Reluctant to see appointed academic supervisors was not only caused by unfriendly supervisors but also caused by opposite-sex issues. We found that Male and female Muslim students are very reluctant to meet their opposite-sex supervisors in face to face advising sessions. Opposite sex service resistance is commonly found within communities with strong value holders. Reluctant to interact with different sex status might be affected by experience sex segregation during childhood or early adulthood ${ }^{28}$. Other studies also argue that students who have the personal belief from their previous life experience tend to bring and practice it in their future life ${ }^{29}$. The findings are consistent with the phenomena of this study, which most Muslim students who graduated from Islamic boarding tend to resist to engage with their opposite-sex academic advisor when they enter a university.

Islamic teaching forbid Muslim women or men to have direct contact with non-mahram ${ }^{30,31}$. Certain Muslim communities strongly hold the belief, in particular, those who graduate from Islamic boarding schools. As a result, when they enter the university education system, they bring those beliefs within campus life. 
We found that some Muslim students who have education background from strong Islamic boarding school tend to believe that direct contact with nonmahram (opposite sex advisors) is forbidden as they were taught in Islamic boarding schools. It is no doubt that students who were appointed opposite sex academic supervisors experience feel lack comfortable to see them.

Reluctant to express complaints to academic advisors in face to face mode escalate students distress because another channel is limited. The situation may reduce their opportunity to succeed in their studies. While pressure to succeed in university for students in developing countries are higher ${ }^{32}$. An online academic advising service center can become a better solution to increase students' participation in using academic advising service. Active use of academic advising service increases strong rapport between students and advisors, which facilitates an open discussion that is productive for identifying and solving problems ${ }^{10}$.

\section{Conclusion}

This study found that Muslim students are more open to express their feeling and thought during online counseling consultation. Five main themes have emerged during the online consultation, which is distress of bureaucracy complexities, unfair academic treatment, lack channel to express grief, and unfriendly academic advisors. We suspect that the students' openness in expressing sensitive issues through online counseling mode due to high confidentiality and anonymity. Their identities were confidential because all online facilities for consultation did not support self-disclosure except voices when it was conducted through telephone. This highlighted that online counseling is able to encourage students to seek academic support actively. Barriers, such as reluctant to see opposite sex counselor and supervisor's time limitation, can be reduced by online academic advising systems.

Acknowledgement: This work was supported by State Institute for Islamic Studies Centre for Academic Advising.

\section{Conflict of Interest: Nil}

Funding: Funded by State Institute for Islamic Studies (IAIN) Palu budget 2019
Ethical Clearance: Obtained from Research Centre and Ethical Committee of State Institute for Islamic Studies (IAIN) Palu

\section{References}

1. Cooper-Hind, H., Student complaints: an accurate measure of student dissatisfaction? Higher Education Review 2012. 44(3): p. 54-80.

2. Naidoo, P. and D.J. Cartwright, Reflections on the History of South African Student Counseling Services: Achievements, Challenges, and a Way Forward. Journal of College Student Psychotherapy, 2018. 32(1): p. 23-41.

3. Hunt, J. and D. Eisenberg, Mental Health Problems and Help-Seeking Behavior Among College Students. Journal of Adolescent Health, 2010. 46(1): p. 3-10.

4. Eisenberg, D., J. Hunt, and N. Speer, Mental health in American colleges and universities: variation across student subgroups and across campuses. J Nerv Ment Dis, 2013. 201(1): p. 60-7.

5. Surette, T.E. and M.L. Shier, A Common Factors Approach to Supporting University Students Experiencing Psychological Distress. Journal of College Student Psychotherapy, 2017. 31(2): p. 112-131.

6. Eisenberg, D., E. Golberstein, and J. Hunt, Mental Health and Academic Success in College. B.E. Journal of Economic Analysis \& Policy, 2009. 9(1): p. 1-35.

7. Wyatt, T.J., S.B. Oswalt, and Y. Ochoa, Mental Health and Academic Performance of First-Year College Students. International Journal of Higher Education, 2017. 6(3): p. 178-187.

8. Harrison, T.R., My professor is so unfair: Student attitudes and experiences of conflict with faculty. Conflict Resolution Quarterly, 2007. 24(3): p. 349368.

9. Harris, N., Resolution of student complaints in higher education institutions. Legal Studies, 2007. 27(4): p. 566-603.

10. Al-Ansari, A., et al., Academic advising and student support: Help-seeking behaviors among Saudi dental undergraduate students. The Saudi Dental Journal, 2015. 27(2): p. 57-62. 
11. Wong, K.P., et al., Preferences for Online and/ or Face-to-Face Counseling among University Students in Malaysia. Frontiers in Psychology, 2018. 9: p. 64.

12. Strauss, A. and J.M. Corbin, Basics of Qualitative Research: Grounded Theory Procedures and Techniques. 2 ed. 1998, California, USA: Sage Publications, Inc.

13. Graham, J.R., C. Bradshaw, and J.L. Trew, Addressing Cultural Barriers with Muslim Clients: An Agency Perspective. Administration in Social Work, 2009. 33(4): p. 387-406.

14. Humeidan, M., University Counseling Center, in Counseling Muslims: Handbook of Mental Health Issues and Interventions, S. Ahmed and M.M. Amer, Editors. 2012, Routledge Francis and Taylor Group: New York. p. 385.

15. Abu Raiya, H. and K.I. Pargament, Religiously integrated psychotherapy with Muslim clients: From research to practice. Professional Psychology: Research and Practice, 2010. 41(2): p. 181-188.

16. Stoltenberg, C.D., T. Pace, and J.E. Maddux, Cognitive style and counselor credibility: Effects on client endorsement of Rational Emotive Therapy. Cognitive Therapy and Research, 1986. 10(2): p. 237-243.

17. Cropanzano, R., Causes and Coonsequences of Applicant Perceptions of Unfairness, in Justice in the Workplace: From Theory to Practice. 2001, Lawrance Erlbaum Associates: London.

18. Pillutla, M.M. and J.K. Murnighan, Unfairness, Anger, and Spite: Emotional Rejections of Ultimatum Offers. Organizational Behavior and Human Decision Processes, 1996. 68(3): p. 208224.

19. Srivastava, J., F. Espinoza, and A. Fedorikhin, Coupling and decoupling of unfairness and anger in ultimatum bargaining. Journal of Behavioral Decision Making, 2009. 22(5): p. 475-489.

20. Lee, J.J. and C. Rice, Welcome to America? International student perceptions of discrimination. Higher Education, 2007. 53(3): p. 381-409.
21. Brown, K.M., The role of internal and external factors in the discontinuation of off-campus students. Distance Education, 1996. 17(1): p. 4471.

22. Oldfield, B.M. and S. Baron, Student perceptions of service quality in a UK university business and management faculty. Quality Assurance in Education, 2000. 8(2): p. 85-95.

23. Seidler, V.J., Rejection, Vulnerability, and Friendship, in Men's Friendships, P.M. Nardi, Editor. 1992, Sage Publication: London. p. 15.

24. Wiseman, J.P., Friendship: Bonds and Binds in a Voluntary Relationship. Journal of Social and Personal Relationships, 1986. 3(2): p. 191-211.

25. Zhang, X., et al., Advising Students for Success in Higher Education: An All-Out Effort. Journal of College Student Retention: Research, Theory \& Practice, 2019. 21(1): p. 53-77.

26. Young-Jones, A.D., et al., Academic advising: does it really impact student success? Quality Assurance in Education, 2013. 21(1): p. 7-19.

27. Willging, P.A. and S.D. Johnson, Factors that Influence Students' Decision to Dropout of Online Courses. Journal of Asynchronous Learning Networks, 2009. 13(3): p. 115-127.

28. Mehta, C.M. and J. Strough, Sex segregation in friendships and normative contexts across the life span. Developmental Review, 2009. 29(3): p. 201220.

29. Shakeriana, A., et al. Investigating Personality Trait and Pre-Marital Affair with Opposite Sex among University Students of Sanandaj City. in 4th World Conference on Psychology, Counselling and Guidance WCPCG-2013. 2014. ScienceDirect.

30. Rehman, T.F., Women Who Choose Islam. International Journal of Mental Health, 2003. 32(3): p. 31-49.

31. Srimulyani, E., Muslim Women and Education in Indonesia: The pondok pesantren experience. Asia Pacific Journal of Education, 2007. 27(1): p. 85-99.

32. Bettmann, J.E., et al., Measuring Anxiety and Depression in Ghanaian and U.S. College Students. Journal of Multicultural Counseling and Development, 2019. 47(2): p. 119-130. 